\title{
Some Records of the Canada Goose Breeding in Southwestern Saskatchewan
}

by J. Robert Caldwell, Ducks Unlimited (Canada), Saskatoon

Today, like the pioneers, we still have the privilege of seeing many forms of wildlife in their native environment. One of the favourites is the Canada Goose, known to the scientific world as Branta canadensis. While many may not realize it, this bird nests fairly commonly on lakes and reservoirs in southwestern Saskatchewan. This article deals with its occurrence in Saskatchewan south of the South Saskatchewan River and west of Swift Current.

The large race of Canada Goose (Branta canadensis moffiti) found here is chiefly a bird of the open grassland. Aldrich (1946) describes its range as follows: Great Plains and Great Basin regions of the United States and Canada from eastern Washington and Oregon and northeastern California, to Great Salt Lake, Utah, west-central Nebraska and northeastern North Dakota, north into the southern portions of the Prairie Provinces and British Columbia.

We can only speculate as to the abundance of this bird in Saskatchewan prior to the historic period. Mr. M. Hitchcock of Maple Creek, tells me (pers. corres., 1958) that in the early 1900's geese could be found along small lakes and creeks throughout the southwest. In the summer of 1905 Bent (1907) reported it as being common on all the larger lakes in southwestern Saskatchewan. On June 2,1905 , he found two nests each containing six eggs on a small island in Crane Lake. Nests with eggs at this date, he thought, indicated re-nesting since geese normally are early breeders. Chapman (1908) noted, during a boat trip on Crane Lake on June 19, 1908, that ducks and geese were the dominant species of bird life. S. A. Mann of Skull Creek says that he knows of geese nesting in his district as early as 1910 (pers. corres., 1958).

Undoubtedly the influx of settlers had an adverse effect on Canada Geese. Many of the homesteaders had little aesthetic appreciation for wildlife; game laws were non-existent and even had they been enacted, enforcement over such a large area would have been almost impossible. A large and sometimes vociferous bird, the Canada is usually quite conspicuous in early spring when it is nesting. Consequently it was particularly vulnerable to the depredations of man. Mr. Hitchcock contends that the principal factor contributing to the decrease in geese nesting in the southwest prior to the drought of the 1930's was the advent of the grain farmer. Old timers tell me that it was common practice to take goose eggs and hatch them under a domestic hen. It is evident that people shot or molested these birds whenever the opportunity presented itself.

But in the "dirty thirties" drought replaced man as the chief enemy of the geese. By 1937 almost every lake in southern Saskatchewan was dry and the Canada Goose was nearly eliminated as a nesting bird. Only remnants of the population could be found, some along the South Saskatchewan River and a few persisting on the half-dozen lakes that still remained. Disrupted too, was the tradition of geese returning to nest on or near the lake on which they had been raised. In some instances the pattern of migration was also changed. For example, the number of geese stopping at Crane Lake each fall in the past few years has never approached the concentrations observed there prior to the 1930's.

Water levels started to improve somewhat by the 1940's; by the midfifties, ponds, sloughs and lakes were brimming. The water had come back and so did the geese. By 1958 broods were being raised on most of the large lakes and reservoirs. Several factors, I think, contributed to the re-population of the Canada Goose, and foremost may be the wildlife refuge system in the state of Montana. Geese from the Bowdoin National Wildlife Refuge, near Malta, Montana, most certainly have spread northward to nest near Val Marie. From here they may have fanned out north and west. Another factor which benefits this bird is the presence of many large community pas- 
tures throughout the southwest, which have been designated as game preserves, where geese can nest unmolested by humans. Also, since the thirties, P.F.R.A. and Ducks Unlimited have built many water impoundments that retain water even through prolonged periods of drought. A number of these reservoirs are being used by nesting geese. I believe, too, that people now are much more aware of the need for protection of various wildlife species, especially one as universally popular as the Canada Goose.

In 1958 Ducks Unlimited began to census goose broods (systematically) on lakes and reservoirs in, the southwest. The results of this survey. are given in Table 1.

Table 1

Brood Counts on Eight Lakes and Reservoirs With Yearly Totals From 48 Other Areas.

\begin{tabular}{|c|c|c|c|c|c|}
\hline Names of Area & 1959 & 1960 & 1961 & 1962 & $\begin{array}{l}\text { Water Conditions in } \\
1962\end{array}$ \\
\hline 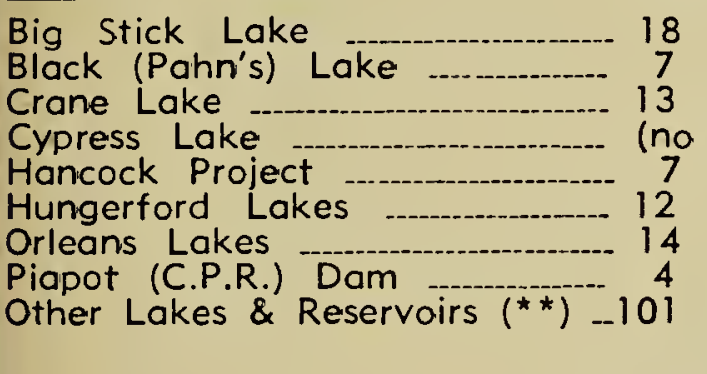 & $\begin{array}{r}15 \\
7 \\
15 \\
\text { fig.) } 5 \\
10 \\
9 \\
10 \\
10 \\
93\end{array}$ & $\begin{array}{r}8 \\
6 \\
21 \\
11 \\
5 \\
8 \\
3 \\
12 \\
111\end{array}$ & $\begin{array}{r}3 \\
8 \\
2 \\
17 \\
7 \\
11 \\
10 \\
8 \\
125\end{array}$ & $\begin{array}{l}2^{\star} \\
6^{\star} \\
7^{\star} \\
13^{\star} \\
6 \\
13 \\
2 \\
6^{\star} \\
91^{\star}\end{array}$ & $\begin{array}{l}\text { lake low } \\
\text { lake dry by fall } \\
\text { water levels low } \\
\text { water levels low } \\
\text { a number of areas } \\
\text { dry }\end{array}$ \\
\hline
\end{tabular}

Totals

$176 \mp$

$174+$

$185+$

$191 \mp 146 \mp$

* data for 1962 through courtesy Department of Natural Resources.

* * projected brood counts included here.

With one or two exceptions, the lakes and reservoirs tabulated are the most productive in the district. These counts should not be construed as giving anything but minimum totals for it is difficult to locate every brood in the region. In a number of inștances, we projected the brood counts to lakes where we knew geese nested and water remained, but which time did not permit us to census every year. These figures form part of the total under the general heading "Other Lakes and Reservoirs."

Data in Table 1 indicate a gradual increase in the number of broods until 1961, followed by a 24 per cent decline. This may be a reflection of the drought of the past several years that has again greatly reduced surface water over the whole area. Such being the case, we might anticipate an increase in the number of geese nesting on the more stable lakes. Brood counts do not bear this out. Have these areas reached their carrying capacity or is the decline due to over-harvesting or to other causes? These are among the many questions that must be answered by wildlife biologists seeking ways of maintaining and increasing Canada Goose populations.

No one can predict the future. Nevertheless, a species that requires so little in order that it may continue to provide us with pleasure should be worthy of our assistance. If man has foresight, there is no valid reason why generations hence should not always be able to see the Canada Goose in its natural haunts.

\section{LITERATURE CITED}

Aldrich, J. W. 1940. Speciation in the Whitecheeked Geese. Wilson Bull., 58:94-103.

Bent, A. C. 1907. Summer birds of southwestern Saskatchewan. Auk, 24:407-430.

Chapman, F. M. 1908. Camps and cruises of an ornithologist. D. Appleton and Company, New York.

\section{BIRDWATCHERS WANTED}

Several years ago a study of birds in relation to their environment was begun in Europe. The birdwatchers note the number of birds of each species seen along a transect of 1.25 miles (or multiples thereof) through reasonably uniform vegetation: e.g., meadow, forest, lakeshore, etc. Transects are also studied in towns which are considered "gardens." As the transect is a "line," the observers do not crisscross through the landscape, but always make their observations from the road, trail or waterway which forms the line, and as far into the field as is feasible. Observations are made every two weeks. The results of the first two years show a strong binding of certain birds to certain types of landscape. I have been asked whether it would be possible to set up a similar project here. For this study a number of birdwatchers and a co-ordinator are required. I shall be available as co-ordinator; if you, the birdwatchers, are interested in co-operating, please write the following information:

1. Name and address. 2. Number of tran(Continued on Page 67) 